\title{
VAR MODEL UNTUK ANALISIS FOREIGN DIRECT INVESTMENT DI INDONESIA
}

\author{
Dede Ruslan \\ Fakultas Ekonomi Universitas Negeri Medan \\ Sumatera Utara, Indonesia \\ email: dras ruslan@yahoo.com
}

\begin{abstract}
Vector Autoregresive model is used to gives a more comprehensive view of how the relationship of FDI to economic growth, trade, exchange rate, the output value of the industry, and the interest rate in Indonesia. This study provides empirical evidence about the relationship which are interrelated to each other among the variables analyzed. By using VAR can analyze the impact of FDI on economic growth with other variables. The empirical results of whole analysis to give an answer to the original question posed in this study relate to how economic growth has been achieved, what the role of FDI and other spillovers in this process. Through the VAR model, the interdependence between the variables FDI, GDP, Trade, Industrial Output Value, Exchange Rate and Interest rates have been investigated in long-term relationships through cointegrating vectors and the short-term impact of the VAR model. Correlation of dynamic variables have been captured by the analysis of variance decomposition and impulse response.
\end{abstract}

Keywords: FDI, Pertumbuhan ekonomi, variabel makro dan VAR model

\section{PENDAHULUAN}

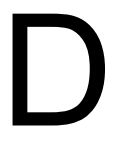

alam era globalisasi ekonomi dunia dan persaingan yang semakin ketat tidak hanya dalam perdagangan, namun juga dalam perusahaan transnasional (transnational corporation-TNC) saat ini, seperti pelaksanaan Kesatuan Eropa (EU), Penjanjian Perdagangan Bebas Amerika Utara (NAFTA), Kawasan Perdagangan Bebas ASEAN (AFTA), sedikit banyak telah menjadi bukti adanya pergerakan aliran modal dan masuknya aliran investasi asing langsung (FDI) yang semakin

QE Journal | Vol.03 - No.02 June 2014 - 85 
deras, yang selanjutnya berdampak pada keterbukaan ekonomi di berbagai negara, khususnya negara sedang berkembang. Keterbukaan tersebut dapat diartikan sebagai keterbukaan ekonomi, keterbukaan kebijakan modal maupun keterbukaan informasi. Sehingga, tidak heran beberapa peneliti seperti Pfaffermafr (1994), Gopinath (1999) dan Liu (2001) menguji hubungan antara FDI dengan pertumbuhan eksport dan GDP. Mereka menyimpulkan bahwa investasi asing langsung (FDI) tidak hanya secara langsung mendorong pertumbuhan ekonomi tetapi juga secara tidak langsung terjadi interaksi timbal balik antara FDI dengan pertumbuhan ekonomi, melalui interaksi dari FDI dengan sumber daya manusia (human capital) sehingga memberikan dampak positif yang sangat kuat terhadap pertumbuhan ekonomi di negara-negara berkembang.

United Nations Conference on Trade and Development, UNCTAD (2001) menemukan bahwa pertumbuhan FDI di seluruh dunia mengalami peningkatan yang signifikan sejak tahun 1990,1997 dan tahun 2000, yakni berturut-turut USD 209 juta, USD 437 juta, dan USD 1.118 juta. Sedangkan berdasarkan data UNCTAD (2007), dari 1980 hingga 2006, arus masuk FDI di negara berkembang meningkat lebih dari 30 kali, dari US \$ 8,4 miliar pada tahun 1980 menjadi US \$ 412., milyar pada tahun 2006. Hasil penelitian Panayotou (1998) menyebutkan bahwa lebih dari 80\% modal swasta dan 75\% dari FDI sejak tahun 1990 mengalir ke negara-negara dengan pendapatan menengah (middle income countries). Untuk kawasan Asia nilainya mencapai 60\% dan Amerika Latin sebesar 20\%. Sedangkan World Bank (1999) memperkirakan bahwa investasi asing di negara-negara berkembang akan tumbuh pada tingkat 7-10\% per tahun sampai akhir dekade ini. Hal ini didorong oleh dampak liberalisasi, privatisasi, inovasi teknologi, penurunan biaya trasportasi, telekomunikasi, mobilitas modal dan pertumbuhan integrasi keuangan. UNCTAD (2001), mengemukakan bahwa pertumbuhan FDI di seluruh dunia mengalami peningkatan yang signifikan sejak tahun 1990,1997 dan tahun 2000, yakni berturut-turut USD 209 juta, USD 437 juta, dan USD 1.118 juta. Sedangkan UNCTAD (2005) menyatakan bahwa peningkatan aliran FDI ke negara Asia Tenggara merupakan peningkatan terbesar di Asia yang disumbangkan oleh negaranegara anggota ASEAN. Aliran masuk FDI ke Thailand mengalami peningkatan dari US $\$ 1,4$ trilyun di tahun 2004 menjadi US\$3,7 trilliun di tahun 2005, bahkan Indonesia untuk tahun 2012 mengalami peningkatan 
sampai dengan 307,07\%, dimana tahun 2009 senilai US\$ 4,8 trilliun naik menjadi 19,853 trilliun di tahun 2012 (World Investment Report , 2013).

Data investasi yang di rilis oleh UNCTAD (2012) menunjukkan bahwa dari aspek share atau porsi akumulasi investasi, Indonesia menempati peringkat ke 25 dari 238 negara pada tahun 2011. Porsi investasi asing di Indonesia tercatat sebesar $0.84 \%$ terhadap total investasi asing di seluruh dunia, meskipun masih di bawah Singapura (2.54\%). Namun di kawasan ASEAN, Indonesia sudah menerima porsi investasi melebihi negara-negara tetangga lainnya seperti, Thailand, Malaysia, dan Filipina.

Terjadinya peningkatan FDI ke Indonesia di sebabkan bahwa Indonesia sebagai negara berkembang, sudah pasti berkeinginan untuk meningkatkan pertumbuhan ekonominya. Untuk mencapai pertumbuhan ekonomi yang dikehendaki, maka sebaiknya diperlukan sejumlah investasi yang dibiayai dari tabungan nasional. Tetapi di negara berkembang seperti Indonesia tabungan nasional yang dimiliki tidak mencukupi untuk membiayai invetasi, sehingga Indonesia tidak mempunyai dana yang cukup untuk membiayai pembangunan ekonomi karena terbatasnya akumulasi modal, tabungan nasional serta rendahnya produktivitas dan tingginya konsumsi, sehingga diperlukan sumber dana lain yaitu investasi asing langsung atau penanaman modal asing (Sarwedi, 2002).

Selanjutnya BKPM (2012), nilai investasi asing yang masuk ke Indonesia tercatat sebesar USD 24.5 miliar atau sekitar Rp 240 triliun. Jumlah tersebut mengalami kenaikan dibandingkan tahun sebelumnya yang mencapai USD 19.4 miliar (tumbuh sekitar 26\%). Angka investasi di tahun 2011 juga mengalami peningkatan cukup tinggi dibanding 2010 yang mencapai USD 16.2 miliar (tumbuh sekitar 20\%).

Disisi lain, ada dua hal yang mempengaruhi kegiatan FDI di suatu negara penerima (host country), dalam kaitannya dengan mengapa suatu negara begitu aktif dalam menarik minat investor untuk menanamkan modalnya di suatu negara, yaitu (1) lingkungan atau kerangka kebijakan (policy framework) dan (2) faktor ekonomi (economic determinants). Pertimbangan ekonomi, di satu sisi mejadikan pertimbangan dalam kegiatan FDI. Variabel ekonomi ini antara lain menyangkut akses pasar, sumber daya, dan faktor efisiensi. Kedua variabel ini sebenarnya mendasari mengapa negara-negara berpacu untuk menarik peluang tersebut.

QE Journal | Vol.03 - No.02 June 2014 - 87 
Daya tarik FDI adalah salah satu yang paling strategis bagi negara berkembang untuk meningkatkan pembentukan modal yang dapat menghasilkan tingkat pertumbuhan ekonomi yang lebih tinggi. Selanjutnya interdependensi antara FDIdengan variabel makro lainnya perlu dikaji secara optimal. Terdapat tiga masalah pokok yang sering dikaji dan dianalis dalam suatu penelitian yang terkait dengan aliran masuk Investasi asing langsung (FDI). Antaranya ialah (1) faktor apakah yang menentukan aliran masuk FDI di sebuah di negara baik Negara maju atau di negara sedang membangun, (2) Bagaimana hubungan antara FDI dengan aktivitas perdagangan negara (ekspor dan impor), (3) Berapa sumbangan FDI terhadap pertumbuhan ekonomi. Dalam tulisan ini yang akan dikaji dirumuskan masalahnya sebagai berikut: Apakah dalam jangka panjang antara FDI, dengan variable trade, Nilai Output industri, nilai tukar, tingkat bunga dan pertumbuhan ekonomi memiliki keterkaitan hubungan satu sama lain?

Definisi tentang FDI sangatlah komplek, berbagai literatur yang didasarkan pada berbagai kajian-kajian analisis memberikan pengertian diantaranya adalah OECD (2009) dan (IMF, 2005) menurut definisi benchmark OECD dan Neraca pembayaran IMF, FDI merupakan rekleksi atau cerminan keinginan penduduk suatu negara yang sudah menjalankan investasinya di dalam perekonomian negaranya sendiri untuk melakukan investasi secara langsung pada perekonomian negara lainnya dalam bentuk pengembangan perusahaannya. Keinginan langsung tersebut menyiratkan adanya hubungan jangka panjang antara investasi secara langsung di suatu negara yang dipilih dengan manajemen perusahaan yang dimilikinya. (OECD, 2009 dan IMF, 2005).

Selanjutnya World Invesment Report mendefinisikan FDI sebagai suatu investasi yang melibatkan hubungan jangka panjang dan mencerminkan keinginan menjalankan investasi dalam jangka panjang serta pengendalian yang dilakukan oleh penduduk dalam perekonomian suatu negara sebagai investor asing langsung ke penduduk di suatu perekonomian negara lainnya sebagai suatu pengusaha afiliasi atau afiliasi asing (UNCTAD, 2009:243)

Dalam UU Nomor 25 Tahun 2007 Tentang Penanaman Modal yang merupakan produk hukum terbaru penyempurnaan dari Undang-Undang Nomor 1 Tahun 1967 tentang Penanaman Modal Asing dan Undang-

QE Journal | Vol.03 - No.02 June 2014 - 88 
Undang Nomor 6 Tahun 1968 tentang Penanaman Modal Dalam Negeri, kegiatan FDI didefenisikan sebagai: "Penanaman modal asing adalah kegiatan menanam modal untuk melakukan usaha di wilayah negara Republik Indonesia yang dilakukan oleh penanam modal asing, baik yang menggunakan modal asing sepenuhnya maupun yang berpatungan dengan penanam modal dalam negeri." Dari pengertian tersebut paling tidak ada unsur pokok yang dapat diambil yakni: (1) Kegiatan investasi haruslah dilakukan secara langsung (2) umumnya bersifat Private Investment dan dilakukan oleh perusahaanperusahaan, dimana resiko atas investasi ditanggung oleh investor itu sendiri.

Dari berbagai definisi tersebut di atas dapat disimpulkan bahwa FDI adalah sebagai suatu investasi jangka panjang yang dilakukan secara langsung oleh investor asing di dalam suatu bidang usaha warga negara domestik atau sebagai suatu jenis kegiatan investasi lintas negara, dimana kontrol terhadap operasional perusahaan di negara penerima (host country) sepenuhnya dipegang oleh perusahaan negara asal (home based country).

Berdasarkan UNCTAD (2006) dilakukannya FDI tersebut didasarkan pada motif investasi yang dilakukan oleh TNC mengenai ekpektasi keuntungan atau profit global kegiatan bisnis TNC. Terdapat empat motif penting yang mendasari kegiatan FDI oleh TNC, khususnya di negara-negara berkembang berdasarkan urutannya:

a) Market-seeking, merupakan motif utama dari hampir semua kegiatan TNC di negara berkembang, yakni upaya melayani pasar secara langsung.

b) Efficiency-seeking, adalah motif untuk mengurangi biaya produksi agar dapat bersaing dipasar baik dalam maupun luar negeri. Terutama upah tenaga kerja yang murah di negara-negara berkembang.

c) Resource-seeking, motif penguasaan akan sumber daya walaupun relatif kecil tetapi masih merupakan salah satu motif TNC melakukan FDI, khususnya TNC yang bergerak di sektor primer.

d) Created-asset seeking (an asset - augmenting strategy). Terkait dengan investasi aset-aset produktif, misalnya pembelian sebuah pabrik, pembelian tanah, peralatan, dan penanaman kembali modal

Hal-hal tersebut di atas menyebabkan FDI memiliki karakteristik yang relatif lebih stabil, serta mampu meningkatan output dan pendapatan 
kepada negara penerima (host countries). Selain itu dalam Asian Development Outlook (2004) dinyatakan bahwa mengalirinya FDI dari negara-negara maju ke negara berkembang khususnya di Asia akan mempengaruhi perekonomian.

Berbagai teori telah dikembangkan sejak 1960-an untuk menjelaskan FDI. Teori-teori memberikan informasi tentang faktor penentu yang bisa menjelaskan aliran FDI yang melibatkan pendekatan secara mikro ekonomi (misalnya, aspek organisasi) dan pendekatan makro ekonomi (misalnya, alokasi sumber daya) (Dunning dan Lundan, 2008).

Dalam pendekatan ekonomi mikro, teori FDI difokuskan pada karakteristik perusahaan secara spesifik yang mempengaruhi pengambilan keputusan perusahaan tersubut untuk melakukan investasi, misalnya, teori ketidaksempurnaan pasar. Sedangkan dalam pendekatan ekonomi makro teori investasi asing langsung berusaha untuk menganalisis karakteristik suatu negara yang menjadi arus FDI di dalam dan di negara-negara tersebut, seperti teori internalisasi siklus produk. Sedangkan Faeth (2009) menyatakan bahwa dimensi mikro meliputi faktor intrinsik perusahaan itu sendiri, seperti keuntungan pemilik (profit), penghematan biaya dan skala ekonomi, sedangkan dimemsi makro seperti hambatan masuk,ketersediaan sumber daya, stabilitas politik, risiko negara dan ukuran pasar, antara lain (Faeth,2009)

Terdapat lima teori yang ada di dalam literatur ekonomi internasional yang menjelaskan tentang FDI yaitu (1) Model Mac Dougall-Kemp dan Makro Keuangan dan Teori Nilai Tukar (The MacDougall-Kemp Model and Macro Financial and Exchange Theories); (2) Teori Organisasi Industri; (3) Produk Life Cycle Hipotesis, (4) Teori Internalisasi dan (5) Paradigma Eklektik Produksi International Model (Model OLI). (Hongtian, 2011)

Teori-teori FDI meyakini masuknya FDI ke host country akan diikuti dengan apa yang dikenal dengan istilah "spillover effect" seperti, transfer of technology, inovasi-inovasi perbaikan dan pembentukan human capital, know-how, perbaikan management skill, keahlian entrepreneur, mendorong dan membantu investasi dalam negeri dalam berbagai bentuk, misalnya partnership, penyediaan bahan kebutuhan industri, pemasaran hasil produksi, dengan resiko usaha relatif kecil dan lebih profitable dan lain-lain.

QE Journal | Vol.03 - No.02 June 2014 - 90 
Ekternalitas dari kegiatan FDI ini dapat diterima melalui tiga saluran penting yakni: demonstration effect, persaingan, dan labor turnover.

1. Efek Demonstrasi sering juga disebut sebagai kegiatan 'imitation' atau 'learning-by-watching effect'. Karena FDI dianggap akan melibatkan teknologi dan managing skills yang lebih baik dari pada yang dimiliki negara host country, maka ada kecenderungan akan di transfer dalam proses produksi perusahaan-perusahaan lokal (Wang and Blomström, 1992).

2. Masuknya FDI melalui kegiatan perusahaan asing juga akan meningkatkan derajat persaingan diantara perusahaan-perusahan untuk berkerja lebih efisien, tentu dengan menggunakan teknologi yang lebih baik dari sebelumnya (Kokko dan Zejan, 1996).

3. Sedangkan saluran labor turnover terjadi ketika pekerja yang bekerja di perusahaan-perusahaan asing telah menerima pelatihan-pelatihan teknologi dan keahlian manajemen yang lebih maju berpindah ke perusahan-perusahan lokal atau menjalankan sendiri perusahaannya dengan memanfaatkan pengetahuan yang diterimanya tadi. (Fosfuri et al, 2001).

Dalam model neo-klasik, dampak FDI terhadap pertumbuhan output dibatasi oleh adanya hasil yang semakin menurun (diminishing return) di modal fisik (physical capital). Oleh karena itu, FDI hanya bisa berdampak pada tingkat output per kapita dan tidak pada laju pertumbuhannya. Dengan kata lain, tidak dapat mengubah tingkat pertumbuhan output dalam jangka panjang. Dengan demikian, FDI tidak dianggap sebagai mesin pendorong pertumbuhan ekonomi. Namun dalam konteks teori pertumbuhan endogen, FDI justru dapat mempengaruhi tidak hanya tingkat output per kapita, tetapi juga laju pertumbuhan. FDI dapat dianggap sebagai mesin pendorong pertumbuhan ekonomi melalui adanya peningkatan teknologi baru dan peningkatan tenaga kerja terampil. Dengan demikian FDI meliliki pengaruh terhadap pertumbuhan ekonomi melalui spillovers effeknya yang terjadi. Dalam konteks ini, dampak FDI terhadap perekonomian home country dapat dianalisis melalui dampaknya pada faktor-faktor yang mendorong pertumbuhan ekonomi, seperti pembentukan modal, pekerjaan, human capital atau modal manusia, ekspor, dan teknologi. Akibatnya, FDI telah diintegrasikan ke dalam teori 
pertumbuhan ekonomi sebagai "pendekatan keuntungan-dari-FDI (gainsfrom-FDI approach)" (Graham dan Krugman, 1995).

Pada prinsipnya, hubungan antara FDI dengan perdagangan masih belum jelas secara teoritis. Pandangan tradisional menyatakan dalam konteks Heckscher-Ohlin model barang-barang dan jasa bergerak secara substitusi dengan faktor penggerak lainnya. Terjadinya mobilitas barang tersebut disebabkan karena adanya perbedaan faktor harga diantara negara-negara tersebut. Pergerakan tersebut akan menghilangkan perbedaan harga di kedua barang dan faktor pasar tersebut, sehingga menghilangkan dasar perdagangan. Kemudian, hambatan perdagangan akan meningkatkan faktor penggerak dan sebaliknya, sehingga ekspor dan investasi asing langsung (FDI) akan mencari cara sebagai alternatif untuk melibatkan diri dalam pasar luar negeri. di pasar luar negeri. Namun, hasil ini akan sangat tergantung pada asumsi-asumsi tertentu dibuat (Schmitz dan Helmberger, 1970 dalam Oscar Bajo - María Montero-Muñoz, 2001)

Dunning (1998) mengatakan hubungan antara FDI dengan perdagangan antar negara adalah saling melengkapi antara satu sama lain. Hal ini menunjukkan wujud hubungan penggenap (pelengkap) antara FDI dengan aktivitas perdagangan antar negara. Pandangan ini juga didukung oleh peneliti-peneliti lain seperti Lipsey,Blomstrom dan Kulchycky (1988) dalam Pain dan Wakelin (1998) yang menghasilkan wujud hubungan pelengkap antara ekspor dengan FDI.

Balassa (1977), Salehi (1989), Bahmani (1990), dan Dodaro (1993) dan Amoateng (1993). Secara umumnya, kebanyakan hasil penelitian mereka menunjukkan hubungan positif yang signifikan antara pertumbuhan ekonomi dengan aktivitas perdagangan antar negara (perkembangan ekspor) dalam Pfaffermayr (1994). Pfaffermayr (1994) memberikan kesimpulan dari hasil kajiannya bahwa aliran keluar FDI dan ekspor dipengaruhi oleh variabel yang sama seperti modal, buruh, skil dan aktivitas penelitian dan pembangunan (R\&D). Dengan menggunakan model pertumbuhan berbentuk endogenous, estimasi sistem persamaan secara simultan dengan menggunakan data tahunan dan cross section di sektor perindustrian di negara Austria menghasilkan kesimpulan bahwa antara investasi asing langsung dengan perdagangan terdapat hubungan yang signifikan dengan sifat hubungan sebagai pelengkap.

QE Journal | Vol.03 - No.02 June 2014 - 92 
Sementara itu hubungan antara nilai tukar riil dan FDI juga menjadi topik penelitian terbaru saat ini. Osinubi, Tokunbo (2009) menyatakan bahwa pergerakan nilai tukar dan munculnya ketidakpastian nilai tukar tampaknya merupakan faktor penting dari investor yang perlu dipertimbangkan dalam keputusan untuk berinvestasi di luar negeri. Banyak literatur tentang pergerakan nilai tukar dan FDI berkonsentrasi pada dua isu, yaitu tingkat nilai tukar dan volatilitas nilai tukar.

\section{METODE PENELITIAN}

Untuk mengetahui saling keterkaiatan Investasi Asing Langsung (FDI), digunakan variabel TRADE, Nilai Output Industri, nilai tukar, dan tingkat bunga serta Pertumbuhan ekonomi baik dalam jangka pendek ataupun jangka panjang.

Pembahasan alat analisis penelitian ini meliputi permasalahan statistik berkaitan dengan estimasi model runtut waktu. Penelitian ini menggunakan data time series yang mempunyai karakteristik khusus dalam analisisnya. Permasalahan yang akan dikemukakan meliputi stasionaritas data dan pengujiannya. Alat analisis yang digunakan untuk menjawab permasalahan penelitian adalah vector autoregression (VAR) model yang terdiri dari enam persamaan berikut:

$$
\begin{aligned}
& \mathrm{FDI}_{\mathrm{t}}=\alpha_{1}+\sum_{j=1}^{k} 1 \mathrm{jDDI}_{\mathrm{t}-\mathrm{j}}+\sum_{j=1}^{k} 1 \mathrm{jPDBK}_{\mathrm{t}-\mathrm{j}}+\sum_{j=1}^{k} 1 \mathrm{jTRADE}_{\mathrm{t}-\mathrm{j}}+\sum_{j=1}^{k} 1 \mathrm{jNOI} \mathrm{I}_{\mathrm{t}-} \\
& 1+\sum_{j=1}^{k} 1 \mathrm{jEXR}_{\mathrm{t}-1}+\sum_{j=1}^{k} 1 \mathrm{j} \mathrm{IR}_{\mathrm{t}-1}+\varepsilon_{1} \\
& \mathrm{PDB}_{\mathrm{t}}=\alpha_{2}+\sum_{j=1}^{k} 2 \mathrm{jDB}_{\mathrm{t}-\mathrm{j}}+\sum_{j=1}^{k} 2 \mathrm{jRAADE}_{\mathrm{t}-\mathrm{j}}+\sum_{j=1}^{k} 2 \mathrm{jNOI}_{\mathrm{t}-\mathrm{j}}+\sum_{j=1}^{k} 2 \mathrm{jEXR}_{\mathrm{t}-\mathrm{j}} \\
& +\sum_{j=1}^{k} 2 \mathrm{jIR}_{\mathrm{t}-\mathrm{j}}+\sum_{j=1}^{k} 2 \mathrm{j} \mathrm{FDI}_{\mathrm{t}-\mathrm{j}}+\varepsilon_{2} \\
& \text { TRADE }_{t}=\alpha_{3}+\sum_{j=1}^{k} 3 \mathrm{jRADE}_{\mathrm{t}-\mathrm{j}}+\sum_{j=1}^{k} 3 \mathrm{jNOI}_{\mathrm{t}-\mathrm{j}}+\sum_{j=1}^{k} 3 \mathrm{jEXR}_{\mathrm{t}-\mathrm{j}}+\sum_{j=1}^{k} 3 \mathrm{jIR} \mathrm{t}-\mathrm{j} \\
& +\sum_{j=1}^{k} 3 \mathrm{jDII}_{\mathrm{t}-\mathrm{j}}+\sum_{j=1}^{k} 3 \mathrm{jPDBK}_{\mathrm{t}-\mathrm{j}}+\varepsilon_{3} \\
& \text { NOI } \mathrm{t}_{\mathrm{t}}=\alpha_{4}+\sum_{j=1}^{k} 4 \mathrm{jNOI}_{\mathrm{t}-\mathrm{j}}+\sum_{j=1}^{k} 4 \mathrm{j} \mathrm{EXR}_{\mathrm{t}-\mathrm{j}}+\sum_{j=1}^{k} 4 \mathrm{jIR}_{\mathrm{t}-\mathrm{j}}+\sum_{j=1}^{k} 4 \mathrm{j} \mathrm{FDI}_{\mathrm{t}-\mathrm{j}}+ \\
& \sum_{j=1}^{k} 4 \mathrm{jPDBK}_{\mathrm{t}-\mathrm{j}}+\sum_{j=1}^{k} 4 \mathrm{j} \mathrm{TRADE}_{\mathrm{t}-\mathrm{j}}+\varepsilon_{4} \\
& \mathrm{EXR}_{\mathrm{t}}=\alpha{ }_{5}+\sum_{j=1}^{k} 5 \mathrm{jEXR} \mathrm{R}_{\mathrm{t}-\mathrm{j}}+\sum_{j=1}^{k} 5 \mathrm{jIR} \mathrm{R}_{\mathrm{t}-\mathrm{j}}+\sum_{j=1}^{k} 5 \mathrm{FDI}_{\mathrm{t}-\mathrm{j}}+\sum_{j=1}^{k} 5 \mathrm{jDBK}_{\mathrm{t}-\mathrm{j}}+ \\
& \sum_{j=1}^{k} 5 \mathrm{jTRADE}_{\mathrm{t}-\mathrm{j}}+\sum_{j=1}^{k} 5 \mathrm{jNOI}_{\mathrm{t}-\mathrm{j}}+\varepsilon_{5} \\
& \mathrm{IR}_{\mathrm{t}}=\alpha_{6}+\sum_{j=1}^{k} 6_{j} \mathrm{IR}_{\mathrm{t}-\mathrm{j}}+\sum_{j=1}^{k} 6_{j} \mathrm{FDI}_{\mathrm{t}-\mathrm{j}+\sum_{j=1}^{k} 6_{j}} \mathrm{PDBK}_{\mathrm{t}-\mathrm{j}}+\sum_{j=1}^{k} 6_{j} \\
& \operatorname{TRADE}_{\mathrm{t}-\mathrm{j}}+\sum_{j=1}^{k} 6_{j} \mathrm{NOI}_{\mathrm{t}-\mathrm{j}}+\sum_{j=1}^{k} 6_{j} \quad \mathrm{EXR}_{\mathrm{t}-j}+\varepsilon 6
\end{aligned}
$$

Dengan, FDI adalah Investasi asing langsung, PDB adalah PDB (ukuran pasar dan kinerja), TRADE adalah Indikator keterbukaan, NOI adalah Nilai Output Industri, EXR adalah Nilai tukar, IR adalah Tingkat bunga, $\mathrm{t}$ adalah

QE Journal | Vol.03 - No.02 June 2014 - 93 
kuartal, dan j adalah jumlah lag (kelambanan) kuartal yang dipilih berdasarkan estimasi terbaik, serta $\varepsilon_{1 \mathrm{t}}, \varepsilon_{2 \mathrm{t}}, \varepsilon_{3 \mathrm{t}}, \varepsilon_{4 \mathrm{t}} \varepsilon_{5 \mathrm{t}}$ dan $\varepsilon_{6 \mathrm{t}}$ merupakan proses white noise (independen terhadap perilaku historis FDI, PDB, TRADE, NOI, EXR, dan IR).

Dalam penelitian ini tahapan pengujian meliputi (1) Pengujian Akar Unit (Init Root Test). (2) Uji Lag Optimal dan (3) Uji Kointegrasi. Dampak goncangan suatu variabel inovasi terhadap variabel-variabel lainnya yang ditelusuri melalui fungsi impulse reponse dan Variance Decomposition.

\section{HASIL DAN PEMBAHASAN}

Seperti tampak dalam Gambar 1. krisis ekonomi dan keuangan yang terjadi sejak pertengahan 1997 di beberapa negara Asia, khususnya di Korea Selatan, Thailand, dan Indonesia telah mengakibatkan kontraksi perekonomian yang dalam. Krisis ekonomi diawali dengan pelarian modal yang berdampak pada penurunan tajam nilai tukar mata uang negara negara tersebut. Depresiasi yang sangat tajam berakibat pada memburuknya kondisi neraca dunia usaha. Kondisi ini diperburuk oleh terhambatnya fungsi intermediasi perbankan sehingga semakin mempersulit ruang gerak dunia usaha.

Tekanan terhadap aktivitas perekonomian semakin berat, seiring dengan diambilnya kebijakan moneter ketat dalam rangka stabilisasi harga dan nilai tukar. Tekanan krisis ekonomi tersebut menyebabkan arus masuk FDI ke Indonesia mengalami penurunan yang kurang menggembirakan, yaitu mengalami penurunan sebesar 1.155 US Juta \$ yaitu dari 4.626 US Juta \$ menjadi 3.473 US Juta \$ atau pertumbuhannya turun hingga $24.96 \%$.

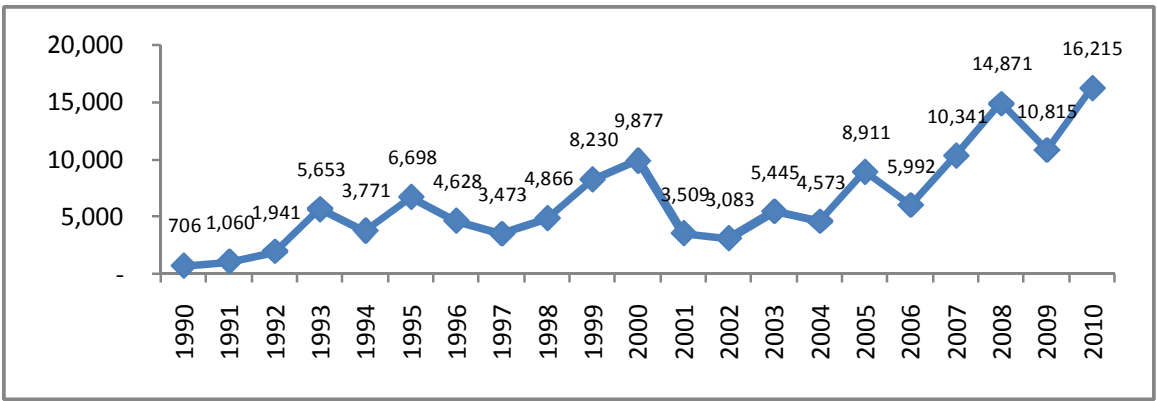

Sumber : Data Statistik BPKM

Gambar 1. Realisasi FDI di Indonesia. 1990 - 2010 (Dalam Juta US\$)

QE Journal | Vol.03 - No.02 June 2014 - 94 
Pada tahun 2000 investasi asing langsung kembali dapat meningkat hingga mencapai angka US\$ 9.8 milyar dan kembali menurun hingga di bawah US\$ 4 milyar pada periode tahun 2001-2002. Penurunan investasi asing di tahun 2001 tidak terlepas dari tingginya risiko investasi akibat masih adanya gangguan keamanan, ketidakpastian penegakan hukum, dan perselisihan perburuhan. Di samping itu, faktor keterbatasan pembiayaan investasi akibat belum pulihnya fungsi intermediasi perbankan dan adanya peraturan-peraturan baru yang terkait dengan penerapan otonomi daerah juga turut membatasi kegiatan investasi. Sentimen negatif berkaitan dengan sempat tertundanya pencairan pinjaman International Monetary Fund (IMF), relatif tingginya suku bunga di dalam negeri, dan lambatnya restrukturisasi utang luar negeri. Sebagai akibatnya, perusahaan cenderung untuk lebih memfokuskan diri pada pembenahan internal, sehingga realisasi investasi baru maupun perluasan kapasitas produksi pada investasi yang telah ada menjadi sangat rendah.

Pada tahun 2002 investasi asing langsung masih mengalami penurunan sebesar 426 juta US\$ atau melambat pertumbuhannya hingga mencapai $12.14 \%$. Secara umum indikasi memburuknya kegiatan investasi dapat dilihat dari menurunnya jumlah persetujuan investasi asing nilai persetujuan investasi dalam rangka Penanaman Modal Asing (FDI) yang merosot sebesar 35.3\%, yakni dari \$15.1 miliar (1.333 proyek) menjadi \$9.7 miliar (1.135 proyek) pada 2002. Selain itu, terdapat pula indikasi beralihnya minat investor asing dari sektor industri ke bidang perdagangan dan reparasi serta bidang jasa lainnya yang tingkat pengembaliannya lebih cepat dan sunk cost (biaya investasi awal yang pasti hilang) yang lebih rendah, (Bank Indonesia. 2002).

Sedangkan untuk tahun 2003 investasi asing langsung mengalami peningkatan pertumbuhan hingga $76.61 \%$. Kegiatan investasi yang meningkat pada 2003 didorong oleh dua faktor utama, yaitu ketersediaan sumber pembiayaan investasi dan perbaikan sentimen pelaku bisnis. Sekitar $80 \%$ dari aliran modal internasional yang masuk ke negara-negara berkembang selama 2003 berbentuk FDI. Di kawasan Asia, FDI lebih banyak masuk ke negara-negara yang memiliki prospek ekonomi baik seperti Cina, Vietnam dan Thailand. Dalam pada itu, Indonesia belum berhasil memanfaatkan kecenderungan peningkatan arus FDI tersebut. Sejalan dengan masih menariknya yield yang ditawarkan oleh pasar modal

QE Journal | Vol.03 - No.02 June 2014 - 95 
domestik, jenis modal asing yang masuk ke Indonesia lebih banyak dalam bentuk investasi portofolio untuk pembelian saham dan obligasi.

Dalam 4 tahun terakhir terlihat bahwa nilai realisasi FDI selalu berada di atas angka US\$ 10 milyar, bahkan nilai realisasi tahun 2008 dapat mencapai angka US\$ 14.8 milyar dan menurun menjadi US\$10.8 milyar ditahun 2009 namun naik kembali menjadi US\$ 16.2 milyar di tahun 2010, (Lihat Gambar 1).

Uji stasioneritas dapat dilakukan dengan uji akar-akar unit yang dikembangkan oleh Dickey Fuller. Alternatif dari uji Dickey Fuller adalah Augmented Dickey Fuller (ADF) yang berusaha meminimumkan autokorelasi. Hasil pengujian stasioneritas data untuk semua variable yang diteliti diperlihatkan pada Tabel 1.

Tabel 1. Hasil Pengujian Akar-akar Unit dengan Level

\begin{tabular}{ccccc}
\hline Variabel & $\begin{array}{c}\text { Nilai Augmented } \\
\text { Dickey-Fuller }\end{array}$ & $\begin{array}{c}\text { Nilai Kritis Mac Kinnon } \\
\text { pada Tingkat Signifikasi } \\
\mathbf{1 \%}\end{array}$ & Prob & Kesimpulan \\
\hline FDI & -2.275945 & -3.592462 & 0.1841 & Tidak Stasioner \\
PDB & 2.598729 & -3.592462 & 1.5054 & Tidak Stasioner \\
TRADE & -4.798300 & -3.592462 & 0.0003 & Stasioner \\
NOI & -1.711215 & -3.596616 & 0.4177 & Tidak Stasioner \\
EXR & -3.503138 & -3.592462 & 0.0126 & Tidak Stasioner \\
IR & -3.593522 & -3.592462 & 0.0100 & Stasioner \\
\hline
\end{tabular}

Sumber : Lampiran pengujian Unit Root test.

Dari hasil uji Augmented Dickey Fuller pada Tabel 1.1 diatas terlihat bahwa hanya variable TRADE dan IR yang stasioner, dimana nilai ADF nya lebih besar dibandingkan dengan nilai Mc Kinnon pada derajat kepercayaan 1\%. Sedangkan variable yang lain tidak stasioner. Untuk itu perlu dilakukan uji akar-akar unit kembali pada $1^{\text {st }}$ difference, yang kemudian diperoleh hasil seperti pada Tabel 2.

Tabel 2. Hasil Pengujian Akar-akar Unit dengan 1 st Difference

\begin{tabular}{ccccc}
\hline Variabel & $\begin{array}{c}\text { Nilai Augmented } \\
\text { Dickey-Fuller }\end{array}$ & $\begin{array}{c}\text { Nilai Kritis Mac Kinnon } \\
\text { pada Tingkat Signifikasi 1\% }\end{array}$ & Prob & Kesimpulan \\
\hline FDI & -8.561516 & -3.596616 & 0.0000 & Stasioner \\
PDB & -1.376687 & -3.596616 & 0.5837 & Tidak Stasioner \\
NOI & -5.211785 & -3.615588 & 0.0001 & Stasioner \\
EXR & -6.755631 & -3.596616 & 0.0000 & Stasioner \\
\hline
\end{tabular}

Sumber : Lampiran pengujian Unit Root test

QE Journal | Vol.03 - No.02 June 2014 - 96 
Berdasarkan pada Tabel 1.2. bahwa setelah diadakan uji Root Test dengan 1 st Difference, diperoleh hasil nilai ADF dari semua variable lebih besar dari nilai MC Kinnon pada derajat kepercayaan 1\%, ini berarti bahwa semua variable telah stasioner. kecuali untuk variabel PDB tidak stationer di 1 st defference tapi stasioner di 2 nd difference. yang ditunjukkan dalam Tabel 3.

Tabel 3. Hasil Pengujian Akar-akar Unit dengan 2 st Difference

\begin{tabular}{ccccc}
\hline Variabel & $\begin{array}{c}\text { Nilai Augmented } \\
\text { Dickey-Fuller }\end{array}$ & $\begin{array}{c}\text { Nilai Kritis Mac Kinnon pada } \\
\text { Tingkat Signifikasi 1\% }\end{array}$ & Prob & Kesimpulan \\
\hline PDB & -34.21176 & -3.610453 & 0.0001 & Stasioner \\
\hline Sumber : Lampiran pengujian Unit Root test & &
\end{tabular}

Sumber : Lampiran pengujian Unit Root test

Karena seluruh variabel yang dianalisis telah stationer, maka langkah selanjutnya bisa dilakukan pengujian penentuan panjang lag optimal. Panjang lag optimal untuk VAR diuji dengan log-likelihood rasio dihasilkan pada panjang lag optimal dengn 2 kelambanan yang cukup untuk memungkinkan melakukan uji kointegrasi dan model ECM.

Uji Kointegrasi dalam variabel yang mempergunakan VAR model memungkinkan untuk mengevaluasi hubungan ekuilibrium dalam jangka panjang. Dari hasil uji Kointegrasi yang dilakukan terlihat bahwa nilai hitung Trace Statistic dan maksimum Eigenvalue lebih besar daripada nilai kritisnya, maka terdapat kointegrasi pada sejumlah variable, ada 6 persamaan kointegrasi pada level 5\% . Dan nilai-nilai dari Trace statistic dan maximum eigenvalue lebih besar dari nilai Critical value, yang berarti adanya hubungan jangka panjang antara variable terbukti.

Berdasarkan hasil analisa Vector Autoregression diketahui bahwa variabel sebelumnya juga berkontribusi terhadap variabel sekarang . Dengan menggunakan dasar lag 1 terlihat bahwa adanya kontribusi positif dan kontribusi negatif dari masing-masing variabel terhadap variabel itu sendiri dan variabel lainnya, dengan demikian variabel dalam penelitian ini saling berkontribusi. Analisis VAR dalam penelitian ini mencakup variabel Investasi Asing Langsung (FDI). Indikator ukuran pasar dan kinerja di proksi dari Produk Domestik Bruto (PDB). Indikator keterbukaan pasar diproksi dari perdagangan ekspor impor (TRADE). Nilai ouuput industri (NOI), nilai tukar (EXR) dan tingkat suku bunga (IR). Berikut tabel kesimpulan kontribusi analisa VAR.

QE Journal | Vol.03 - No.02 June 2014 - 97 
Tabel 4. Hasil Analisis VAR

\begin{tabular}{|c|c|c|}
\hline Variabel & Kontribusi terbesar 1 & Kontribusi terbesar 2 \\
\hline FDI & NOIt-1; -4.4478 & EXRt-1;-1.8516 \\
\hline PDB & $\mathrm{PDB}_{\mathrm{t}-1} ; 1.1983$ & $\mathrm{IR}_{\mathrm{t}-1} ;-0.0700$ \\
\hline TRADE & NOIt-1; 4.9098 & PDBt-1; 0.9153 \\
\hline NOI & NOIt-1; 1.5270 & IR-1; -0.1089 \\
\hline EXR & $\mathrm{EXR}_{\mathrm{t}-1} ; 0.6657$ & NOIt-1; -0.2240 \\
\hline IR & NOIt-1; 0.8361 & $\mathrm{PDB}_{\mathrm{t}-1} ;-0.2659$ \\
\hline
\end{tabular}

Hasil kesimpulan kontribusi analisa VAR menunjukkan kontribusi terbesar satu dan dua terhadap suatu variable, yang kemudian dianalisa berdasarkan hasil peramalan FDI, Suku Bunga (IR), Nilai Tukar (EXR), TRADE, NOI dan PDB Indonesia selama 2000.1 sampai 2010.4 adalah:

1. Variabel FDI

Kontribusi yang paling besar dan positif terhadap FDI adalah nilai output industri (NOI-1) dan NOI-2 masing-masing sebesar 4.4478 dan 4.1249 lalu PDB(-2) sebesar 1.569. Disusul oleh FDI itu sendiri lag 1 dan 2 masing-masing 0.2046 dan 0.0502 . Sedangkan variable lain seperti EXR dan IR memberikan kontribusi negatif.

2. Pertumbuhan Output (PDB)

Kontribusi yang paling besar dan positif terhadap PDB adalah PDB itu sendiri sebesar 1.1983 dan TRADE sebesar 0.0325; nilai tukar (EXR) sebesar 0.039, sedangkan variable yang lain memberikan kontribusi negatif.

3. Variabel TRADE

Kontribusi positif yang paling besar terhadap variabel trade adalah NOI (-1) sebesar 4.9098; nilai tukar (EXR) di lag 1 ataupun 2 masing-masing sebesar 06308 dan 0.8907 selanjutnya disusul oleh PDB(-1) sebesar 0.9153 dan FDI(1) dan FDI(-2) masing masing 0.1383 dan 0.1272.

4. Variabel Nilai Output Industri (NOI)

Kontribusi positif tervadap variabel NOI adalah variabel-variabel FDI (-1). FDI(-2). PDB(-2). NOI(-1). EXR(-2) dan IR(-2), sedangkan yang lainnya memberikan kontribusi negatif. Kontribusi positif terbesar adalah variabel NOI (-1) yaitu sebesar 1.5270.

QE Journal | Vol.03 - No.02 June 2014 - 98 


\section{Variabel EXR}

Kontribusi positif terhadap Nilai Tukar adalah FDI (-1), Trade (-1), NOI(1) dan NOI(-2) serta EXR(-1). Sedangkan variable yang lain memberikan kontribusi negatif.

6. Suku Bunga Libor 6 bulan

Kontribusi positif terhadap Suku Bunga Libor 6 bulan adalah PDB(-2), NOI(-1), EXR(-1) dan IR(-1) sedangkan variabel lainnya memberikan kontribusi negatif.

Berdasarkan hasil penelitian yang di tunjukkan pada 4.16 dengan menggunakan dasar lag 1 dan lag 2 terlihat bahwa adanya hubungan antara FDI, PDB, TRADE, EXR dan IR.

Dalam innovation accounting variabel yang diuji adalah variance decomposition dan impuls respon. Hal ini dilakukan untuk menganalisis hubungan atau korelasi antara masing-masing variable. Analisis impuls respon memberikan visi praktis untuk menafsirkan bagaimana prilaku deret waktu (time series) dalam menanggapi berbagai guncangan dalam system persamaan VAR. Karena semua variabel endogen dalam VAR model, maka setiap kejutan dalam satu persamaan ditransmisikan ke seluruh system, sehingga analisis impuls respon memberikan kesempatan untuk menganalisis bagaimana respon dari satu variabel terhadap variabel lain dalam suatu sistem yang melibatkan satu set variabel lain juga. Fungsi respon impuls dari semua variabel untuk semua jenis guncangan dievaluasi dengan metode dekomposisi Cholesky impuls dalam hal ini urutannya adalah FDI, PDB, TRADE, NOI, EXR dan IR.

Tabel 5. Ringkasan Hasil Impulse Response Function FDI

\begin{tabular}{llccc}
\hline No & Variabel & Jangka pendek & Jangka menengah & Jangka panjang \\
\hline 1 & FDI & + & - & - \\
2 & PDB & + & + & + \\
3 & TRADE & + & + & + \\
4 & NOI & + & - & - \\
5 & EXR & + & - & - \\
6 & IR & + & + & + \\
\hline
\end{tabular}

Variance decomposition bertujuan untuk mengukur perkiraan varians error suatu variable. yaitu seberapa besar perbedaan sebelum dan sesudah shocks, baik yang berasal dari variable itu sendiri maupun variable lain.

QE Journal | Vol.03 - No.02 June 2014 - 99 
Analisis variance decomposition ini dibagi menjadi tiga periode, yaitu periode jangka pendek pada kuartal ke satu, periode jangka menengah pada kuartal ke dua puluh dan periode jangka panjang pada kuartal ke enam puluh. Hasil pengolahan data dengan eviews 6. untuk variance decomposition FDI ditunjukkan dalam Tabel 6.

Tabel 6. Variance Decompositon FDI

\begin{tabular}{|c|c|c|c|c|c|c|c|}
\hline \multirow[b]{2}{*}{ Period } & \multirow[b]{2}{*}{ S.E. } & \multirow[b]{2}{*}{ LOG(FDI) } & \multicolumn{4}{|c|}{ Variance Decomposition of LOG(FDI): } & \multirow[b]{2}{*}{ LOG(IR) } \\
\hline & & & LOG(PDB) & LOG(TRADE) & LOG(NOI) & LOG(EXR) & \\
\hline 1 & 0.463604 & 100.0000 & 0.000000 & 0.000000 & 0.000000 & 0.000000 & 0.000000 \\
\hline 2 & 0.522127 & 85.49660 & 4.826514 & 0.127769 & 6.631550 & 2.792930 & 0.124633 \\
\hline 3 & 0.557118 & 76.11387 & 4.279411 & 4.699026 & 9.409847 & 4.965226 & 0.532617 \\
\hline 4 & 0.570116 & 73.19834 & 4.858146 & 5.043252 & 10.86891 & 5.474495 & 0.556859 \\
\hline 20 & 0.816350 & 50.49943 & 30.81334 & 7.631035 & 6.238032 & 4.251740 & 0.566426 \\
\hline 21 & 0.822136 & 50.28437 & 31.11571 & 7.655121 & 6.150714 & 4.220168 & 0.573917 \\
\hline 22 & 0.826893 & 50.11296 & 31.35879 & 7.672999 & 6.080170 & 4.195351 & 0.579727 \\
\hline 23 & 0.830773 & 49.97645 & 31.55464 & 7.685082 & 6.023583 & 4.175928 & 0.584319 \\
\hline 24 & 0.833941 & 49.86711 & 31.71352 & 7.692719 & 5.977980 & 4.160557 & 0.588111 \\
\hline 25 & 0.836542 & 49.77868 & 31.84354 & 7.697374 & 5.940874 & 4.148122 & 0.591406 \\
\hline 60 & 0.849353 & 49.37008 & 32.44817 & 7.719479 & 5.765836 & 4.082648 & 0.613781 \\
\hline
\end{tabular}

Sumber : Pengolahan Data Dengan Eviews 6.

Berdasarkan hasil penelitian yang ditunjukkan pada Tabel 6 diperoleh hasil bahwa FDI dalam jangka pendek (periode 1), perkiraan error variance sebesar $100 \%$ yang dijelaskan oleh FDI itu sendiri, sedangkan variabel lainnya yaitu PDB, Trade, NOI, EXR dan IR tidak merespon sama sekali, dimana respon variabel-variabel tersebut baru muncul pada periode kedua hingga periode ke 4. Dalam jangka menengah (periode 20) perkiraan error variance sebesar $50.29 \%$ yang dijelaskan oleh FDI itu sendiri. Variabel lain yang paling besar mempengaruhi FDI sebagai variabel kebijakan selain FDI itu sendiri adalah PDB sebesar 30.81\% kemudian trade sebesar 7.63\%. Sedangkan yang paling kecil mempengaruhi FDI adalah IR sebesar $0.56 \%$. Dalam jangka panjang (periode 60) perkiraan error variance sebesar 49.37\% yang dijelaskan oleh FDI itu sendiri. Variable lain yang paling besar mempengaruhi FDI sebagai variabel kebijakan selain FDI itu sendiri adalah PDB sebesar $32.44 \%$ kemudian Trade sebesar $7.72 \%$ sedangkan variabel yang paling kecil mempengaruhi FDI adalah IR sebesar $0.61 \%$. 


\section{SIMPULAN DAN SARAN}

\section{Simpulan}

Melalui serangkaian analisis, penelitian memberikan bukti empiris tentang adanya interdependensi antara FDI dengan PDB, Trade, Nilai Tukar (EXR) dan Tingkat Suku Bunga (IR). Dengan metodologi VAR memungkinkan melakukan analisis untuk tidak hanya menangkap ekuilibrium jangka panjang, tetapi juga mengevaluasi efek total dari limpahan sumbagan variabel lainnya melalui analisis inovasi. Oleh karena itu, analisis VAR memberikan pandangan yang lebih komprehensif pada interdependensi antara FDI dan pertumbuhan ekonomi, dan vaeriabel makro ekonomi (trade, nilai outptut industri, nilai tukar dan tingkat bunga) di Indonesia. Dengan menggunakan analisis VAR dapat menganalisis dampak FDI pada pertumbuhan ekonomi dengan variabel lainnya.

Hasil empiris seluruh analisis memberi jawaban atas pertanyaan awal yang diajukan dalam penelitian ini yang berhubungan dengan bagaimana pertumbuhan ekonomi telah dicapai, apa peran FDI dan spillovers lainnya dalam proses ini. Melalui model VAR, interdependensi antara variabel FDI, PDB, Trade,Nilai Output Industri, Nilai Tukar dan Tingkat bunga telah diselidiki dalam hubungan jangka panjang melalui vektor cointegrating dan dampak jangka pendek dari model VAR. Korelasi dinamis variabel telah ditangkap oleh analisis variance decomposition dan respon impuls. Dari analisis kointegrasi, ditemukan hal-hal sebagai berikut :

\section{Saran}

Adapun saran yang dapat diberikan terkait dengan hasil penelitian adalah FDI cenderung sebagai variable yang menerima kontribusi ketimbang memberi kontribusi maka otoritas moneter sebaiknya tetap memperhatikan variable-variabel berpengaruh tersebut, selain dari Nilai Tukar, IR, dan pertumbuhan PDB ada factor-faktor lain yang terkait dengan kondisi FDI seperti Neraca modal, kebijakan moneter dan fiskal, dan lain-lain. Yang mungkin dapat dijadikan variable tambahan untuk penelitian selanjutnya.

\section{DAFTAR PUSTAKA}

Adegbite E.O and F.S. Ayadi. 2010. The Role of FDI in Economic Development: A Study of Nigeria. World Journal of Entrepreneurship, Management and Sustainable Development, Vol.6 No 1/2. Available from www.worldsustainable.org

QE Journal | Vol.03 - No.02 June 2014 - 101 
Aitken B., Hanson G., and Harrison A. 1997. Spillovers, Foreign Investment, and Export Behavior. Journal of International Economics; 43(1997): 103-32.

Alfaro, L., Chanda, A., Kalemli-Ozcan, S. \& Sayek, S. 2006. How Does Foreign Direct Investment Promote Economic Growth? Exploring the Effects of Financial Markets on Linkages. NBER Working Paper No. 12522, National Bureau of Economic Research, Cambridge, MA

Athukorala P. and Jayasuriya, S. 2004. Complementarity of Trade and FDI Liberalization in Industrial Growth: Lesson from Sri Lanka. 10 Years of ASARC International Conference, The Australian National University, Canberra.

Asian Development Outlook 2004: Foreign Direct Investment in Developing Asia.

Badan Koordinasi Penanaman Modal, berbagai edisi, layanan pengedaan secara elektroni(LPSE) dan Pejabat Pengelelola Informasi dan Dokumentasi (PPID) berbagai terbitan

Bank Indonesia, Buku Laporan Perekonomian Indonesia, berbagai tahun, ISSN 0522-2572

Balasubramanyam V. N., Sapsford D, and Salisu M. 1996. Foreign Direct Investment and Growth in EP and IS Countries. Economic Journal; 106(434):92-105.

Bende-Nabende A., and Ford J.L. 1998. FDI, Policy Adjustments and Endogenous Growth, Multiplier Effects form a Small Dynamic Model for Taiwan, 1959-1995; World Development; 26; pp. 1315-1330.

Blomström, M. and Kokko, A. 2003. The Economics of Foreign Direct Investment Incentives, Working Paper no. 9489, NBER Working Papers, NBER, Cambridge.

Campa, J.M. 1993. Entry by Foreign Firms in the United States under Exchange Rate Uncertainty, Review of Economics and Statistics, 75:614622

Carkovic, M. and R. Levine. 2002. Does Foreign Direct Investment Accelerate Economic Growth?, Working Paper (University of Minnesota Department of Finance, available at: www//ssrn.com/abstract=314924)

Dunning, J.H., 2000. The eclectic paradigm as an envelope for economic and business theories of MNE activity. International Business Review 9, 163-190. 
Dunning J.H. 1982. Explaining the International Direct Investment Position of Countries: towards a Dynamic or Developmental Approach; in Black J. and Dunning J.H. (eds.): International Capital Movements; London: Macmillan; pp 84-121.

Dunning, J. H. 1993. Multinational enterprises and the global economy. Wokingham, England and Reading, Mass.: Addison Wesley.

Dunning J.H. 1998. The European Internal Market Program and Inbound Foreign Direct Investment"; in Dunning J.H. (eds.): Globalization, Trade and Foreign Direct Investment; Oxford: Elsevier; pp. 49-115.

Dunning, J.H.; Lundan, S.M. 2008. Theories of foreign direct investment", in John H. Dunning e Sarianna M. Lundan (org.), Multinational Enterprises and the Global Economy, Cheltenham: Edward Elgar Publishing Limited, pp 79-115.

Dunning, J. H. 1988. The Eclectic Paradigm of International Production: a Restatement and Some Possible Extensions. Journal of International Business Studies. 9: 1-31.

Dunning, J. H. 1993. MNEs, the Balance of Payments and the Structure of Trade.In Multinational Enterprises and the Global Economy.

Effendi, Nury dan Soemantri Femmy M. 2003. Foreign Direct Investment And Regional Economic Growth In Indonesia: A Panel Data Study. Department of Economics, Padjadjaran University July, 2003 Working Paper in Economics and Development Studies No. 200305

Faeth, Isabel. 2009. Determinants of Foreign Direct Investment :A Tale of Nine Theoretical Models. Journal of Economic Surveys. 23, 1 (February): 165-196.

Fu, Xiaolan. 2005. Exports, technical progress and productivity growth in Chinese manufacturing industries. Applied Economics 37(7): 725-739

Froot K, Stein J. 1991. Foreign Direct Investment and Exchange Rate: An Imperfect Market Approach. Wuarterly J. Econ., 1191-1218.

Fujita M., and Hu D. 2001. Regional diversity in China 1985-1994: The effects of globalization and economic liberalization. Annals of Regional Science; 35(3); pp.3-37.

Gorg, H., dan E. Strobl. 2004. Foreign Direct Investment and Local Economic Development: Beyond Productivity Spillovers. Research Paper Series, University of Nottingham No. 2004/11.

Gopinath, M., Pick, D., and Vasavada, U. 1999. The economics of foreign direct investment and trade with an application to the US food

QE Journal | Vol.03 - No.02 June 2014 - 103 
processing industry, American Journal of Agricultural Economics, 81(2), 442-452.

Gopinath, M., Pick, D., and Vasavada, U. 1999. The Economics of Foreign Direct Investment and Trade with an Application to the US Food Processing Industry". American Journal of Agricultural Economics, 81 (2), pp.442-452

Görg, Holger; Greenaway, David. 2001. Foreign direct investment and intra-industry spillovers : a review of the literature Research paper / Leverhulme Centre for Research on Globalisation and Economic Policy, No. 2001,37

Hongtian, Chanida. 2011. Determinants of Foreign Direct Investment Location in China; A Dissertation Submitted in Partial Fulfillment of the Requirements for the Degree of Doctor of Philosophy (Economics) School of Development Economics, National Institute of Development Administration.

Jenkins, C. and Thomas, L. 2002. Foreign direct investment in Southern Africa:determinants, characteristics and implications for economic growth andpoverty alleviation, University of Oxford. Available from http://www.csae.

Kim J., and Hwang S. 2000. The Role of Foreign Direct Investment in Korea"s Economic Development. in Krueger A. and Ito T. edt: The Role of FDI in East Asia Economic Development; Chicago Press.

Krugman, Obsfield .1991. Ekonomi Internasional: Teori dan Kebijaksanaan (terjemahan), Rajawali Press, Jakarta.

Li X., and Liu X. 2005. Foreign Direct Investment and Economic Growth: An Increasingly Endogenous Relationship"; World Development; Volume 33; Issue 3; pp.393-407; March 2005.

Mekki, R. 2005. The Impact of Foreign Direct Investment on Trade: Evidence from Tunisia" in Capital Flows and Foreign Direct Investments in Emerging Markets (Ed. S. Motamen-Samadian). Palgrave Macmillan.

OECD .2000. Main Determinants and Impacts of Foreign Direct Investment on Chinaes Economy. Working Papers on International Investment; Directorate for Financial, Fiscal and Enterprise Affairs; Number 2000, 4.

Pfaffermayr, M. 1994. Foreign direct investment and exports: A time series approach, Applied Economics, 26(4), pp. 337-351.

QE Journal | Vol.03 - No.02 June 2014 - 104 
Shan, J., Tian, G. and Sun, F. 1999. Causality between FDI and economic growth in Foreign Direct Investment and Economic Growth in China (Ed.) W. U. Yanrui, by Edward Elgar Publishers, pp. 140 \pm 56

UNCTAD .2007. World Investment Report: Transaction Corporations, Extractive Industries and Development; United Nations Conference on Trade and Development; United Nations.

UNCTAD. 2009. World Investment Report 2009 (anual report No. UNCTAD/WIR/2009). United Nations Conference on Trade and Development (UNCTAD).

UNCTAD, 2009. World Investment Report 1999 Foreign Direct Investment and the Challenge of Development

UU Nomor 25 Tahun 2007 Tentang Penanaman Modal, Diundangkan di Jakarta pada tanggal 26 April 2007 Menteri Hukum dan Hak Asasi Manusia Republik Indonesi

World Bank .1985. World Development Report; 1984, Washington DC; The World Bank.

World Bank. 1993. The East Asian Miracle: Economic Growth \& Public Policy; Oxford University Press; Oxford.

World Bank. 1999. World Development Report 1999: Entering the 21st Century, The Changing Development Landscape; Oxford University Press; Oxford.

World Bank. 1999. World Development Report 1999: Entering the 21st Century, The Changing Development Landscape; Oxford University Press; Oxford. 